\title{
Toxoplasma polymerase chain reaction on experimental blood samples
}

\author{
A. W. L. JOSS, JEAN M. W. CHATTERTON, R. EVANS and D. O. HO-YEN \\ Scottish Toxoplasma Reference Laboratory, Microbiology Department, Raigmore Hospital, Inverness IV2 3UJ
}

\begin{abstract}
Summary. A two-stage polymerase chain reaction (PCR) assay employing oligonucleotide primers from the $\mathrm{Bl}$ gene of Toxoplasma gondii was developed and assessed for sensitivity and specificity. It was able to detect $T$. gondii DNA from as little as one parasite/sample in mockinfected rat or mouse leucocyte preparations. Parasitaemia was also identified in animals at five stages between 16 and $66 \mathrm{~h}$ after infection with the virulent $R_{H}$ strain, and at 12 stages between 2 and 38 days after infection with the cyst-forming Beverley strain. In the latter case, PCR was more sensitive than animal culture. No cross-reactions were observed in samples containing various opportunist pathogens which may also be found in the blood of immunocompromised patients.
\end{abstract}

\section{Introduction}

Laboratory diagnosis of human toxoplasmosis has relied traditionally on serological tests. This approach was satisfactory when most infections were primary infections in otherwise healthy patients, but now that tests for infection in immunocompromised patients are required, traditional serological tests are inadequate. ${ }^{1.2}$ Patients often do not mount an antibody response which can distinguish current from past infection; specific IgM is frequently not detectable nor is the total antibody elevated. ${ }^{1.2}$ In addition, fetal or congenital infection cannot always be diagnosed by serology alone; demonstration of Toxoplasma gondii by animal inoculation of blood or amniotic fluid is essential to maximise sensitivity.

The polymerase chain reaction (PCR) promises to be the most sensitive rapid means of demonstrating microbial DNA in clinical specimens. ${ }^{5.6}$ The presence of $T$. gondii in brain tissue from two patients with toxoplasma encephalitis was demonstrated by PCR primed with oligonucleotides from the P30 gene. ${ }^{7}$ The parasite can also be demonstrated in simulated infected CSF samples with primers from the B1 gene. ${ }^{8}$ For routine diagnostic purposes, blood samples are more convenient; however, toxoplasma antigen has been demonstrated in such samples with varying degrees of sensitivity and specificity. ${ }^{9-11}$ Toxoplasma DNA was detected with $B 1$ gene primers in the presence of $10^{5}$ white blood cells, a concentration which might be seen in inflamed CSF samples. ${ }^{8}$ In contrast, a positive result was found in only one of 12 infected mouse blood samples tested with the P30 PCR. ${ }^{6}$ The current study examined the suitability of blood as a specimen source for PCR tests on samples from experimentally infected rodents in a B1 oligonucleotide primed assay.

\section{Materials and methods}

\section{Samples}

Axillary vein blood samples were collected in lithium heparin and centrifuged on Histopaque (Sigma) (five volumes of sample on four volumes of Histopaque, at $1250 \mathrm{~g} 12.5 \mathrm{~min}$ ). A broad interphase fraction containing the leucocytes was washed a further three times with sterile phosphate-buffered saline (PBS) $\mathrm{pH}$ 7.4. The final pellets were resuspended in PBS for animal inoculation. PCR samples were given one final wash in water to remove haemoglobin, before resuspension in water and storage at $-70^{\circ} \mathrm{C}$.

T. gondii tachyzoites from Cotton rat peritoneal passage were washed three times with saline and resuspended at an appropriate concentration. Adenovirus, herpes simplex virus, cytomegalovirus, Staphylococcus aureus and Candida albicans were deposited by centrifugation from culture fluid, washed twice in PBS and resuspended at an appropriate concentration. They were reconstituted for testing at concentrations higher than necessary to prove infection - up to at least five-fold the concentration of each virus required to infect a tissue culture tube, $40-2000 \mathrm{cfu} /$ test of $S$. aureus and $50-5000 \mathrm{cfu} /$ test of C. albicans. Pneumocystis carinii cysts were washed from a piece of infected human lung and diluted from a stock containing $5 \times 10^{6} \mathrm{cysts} / \mathrm{ml}$, to working concentrations of $40-1000$ cysts/test.

Samples in water, either fresh or previously frozen, 


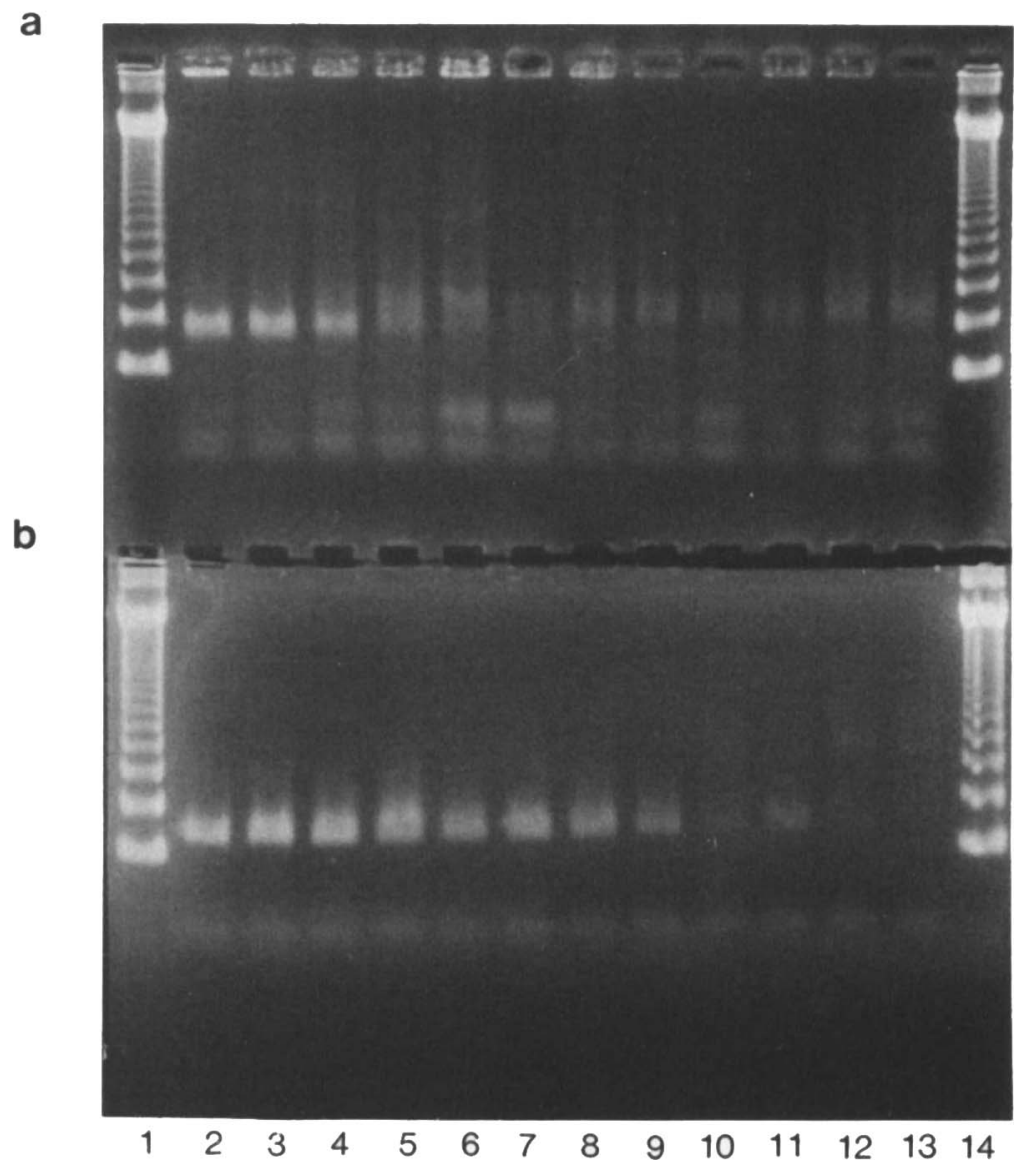

Fig. 1. Sensitivity of primary and nested PCR. Electrophoresis results following primary and nested PCR with primers S1 $14+\mathrm{S} 115$, then S114+S331, respectively. Lanes 1 and 14, 123-bp marker ladder; $2-13,10^{5}, 10^{4}, 10^{3}, 10^{2}, 64,32,16,8,4,2,1,0$ tachyzoites, respectively, diluted in $10^{5}$ rat leucocytes in water. Panel a, primary PCR results; panel b, nested PCR result.

were boiled for $20 \mathrm{~min}$ in $0 \cdot 5$-ml conical Treff tubes (Scotlab, Aberdeen), by a method similar to that used by Burg et al. ${ }^{8}$ In most instances, PCR was performed at this stage. For DNA extraction, the samples were incubated at $55^{\circ} \mathrm{C}$ with shaking for $2 \mathrm{~h}$ in lysis buffer (sodium lauryl sulphate $0.5 \%, 10 \mathrm{~mm} \mathrm{NaCl}, 10 \mathrm{~mm}$ disodium-EDTA, $20 \mathrm{~mm}$ Tris- $\mathrm{HCl}, \mathrm{pH} 7 \cdot 5$ ). This procedure was tested both with and without the addition of proteinase $\mathrm{K}$ (Sigma), final concentration $200 \mu \mathrm{g} / \mathrm{ml}$. The product was successively extracted with water-saturated phenol:chloroform $(1: 1)$, then chloroform:isoamylalcohol $(24: 1)$ and finally precipitated with three volumes of ethanol.

\section{$P C R$}

The PCR was performed in a total sample volume of $50 \mu \mathrm{l}-20 \mu \mathrm{l}$ of test specimen plus $30 \mu \mathrm{l}$ of a reagent mix of the following: water, $10 \times$ buffer concentrate, deoxynucleoside triphosphates (dNTP), primer S114, primer S115 and TAQ polymerase. The $10 \times$ buffer concentrate contained Tris- $\mathrm{HCl}, \mathrm{KCl}, \mathrm{MgCl}_{2}$ and gelatine, $\mathrm{pH} 8 \cdot 3$, and was either produced in-house or supplied by Promega (Southampton). The dNTP contained equimolar dATP, dCTP, dGTP and dTTP (Pharmacia). Primers S114 and S115 were supplied by Severn Biotech, Kidderminster and are equivalent to oligonucleotides 1 and 4 respectively, described by
Burg et $a l .{ }^{8}$ The TAQ polymerase was purchased from ILS Ltd (London) or Promega. The final concentration of each constituent (after addition of $20 \mu \mathrm{l}$ of test sample in water) was $10 \mathrm{~mm}$ Tris- $\mathrm{HCl}, 50 \mathrm{mM} \mathrm{KCl}$, $2.5 \mathrm{mM} \mathrm{MgCl}_{2}$, gelatin $0.01 \%, 0.2 \mathrm{~mm}$ each dNTP and $10 \mu \mathrm{g} / \mathrm{ml}$ each primer. Polymerase was added at 0.7 units/sample. Triton X-100 $0.1 \% \mathrm{v} / \mathrm{v}$ was included in the final mix, either by addition at $0.25 \%$ to the test sample, or supplied in the Promega $10 \times$ buffer concentrate. The reaction volumes were overlaid with $100 \mu \mathrm{l}$ of mineral oil and subjected to 30 temperature cycles of $94{ }^{\circ} \mathrm{C}$ for $1.3 \mathrm{~min}, 53{ }^{\circ} \mathrm{C}$ for $2 \mathrm{~min}$ and $72{ }^{\circ} \mathrm{C}$ for $2.5 \mathrm{~min}$ in a Techne PHC-1 Programmable Driblock (Scotlab) followed by an extension incubation at $72{ }^{\circ} \mathrm{C}$ for $5 \mathrm{~min}$.

The 194-bp product was identified by electrophoresis of $16-\mu \mathrm{l}$ samples (mixed with $4 \mu \mathrm{l}$ of orange $\mathrm{G}$ marker dye $0.01 \%$ in glycerol $50 \% \mathrm{v} / \mathrm{v}$ ), on agarose (BioRad) $2.5 \%$ submarine gels at $133 \mathrm{~V}$ for 30-60 min. Twelve or 24 samples were run/gel along with two or four lanes of 123-bp mol. wt marker ladder (Gibco BRL; $3.5 \mu \mathrm{l}$ including orange $\mathrm{G} /$ lane). Bands were stained by ethidium bromide $1 \mu \mathrm{g} / \mathrm{ml}$ added to the electrophoresis buffer $(0.089 \mathrm{M}$ Tris-borate, $0.0025 \mathrm{M}$ EDTA, pH 8.3) and viewed and photographed on a UVP transilluminator (Scotlab) with a Polaroid DS34 camera (Genetics Instrumentation, Dunmow) with Type 667 Polaroid film. 


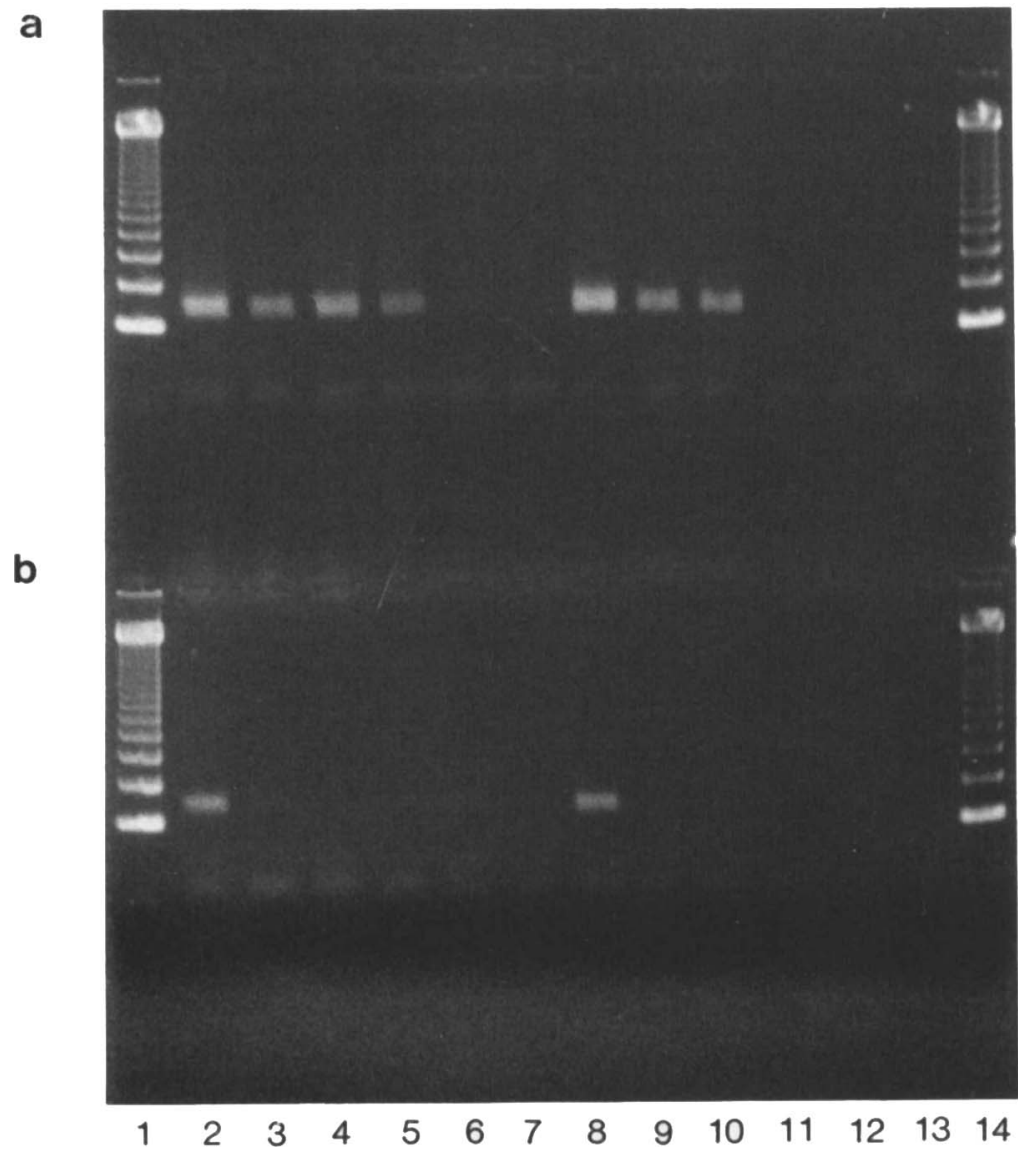

Fig. 2. Effect of sample clarification on PCR sensitivity. Electrophoresis results following two-stage primary and nested PCR with primers $\mathrm{S} 114+\mathrm{S} 115$, then S114 + S331. Lanes 1 and 14, 123-bp marker ladder; $2-7$ and 8-13, sample $=10^{4}, 10^{2}, 32,8,2$, and 0 tachyzoites in water. Panel a. 2-7. boiled sample homogenates: 8-13, samples clarified at $10600 \mathrm{~g} .1 \mathrm{~min}$. before nested PCR; panel b. 2-7, samples clarified before primary PCR : 8-13, samples clarified before both PCR stages.

Nested PCR was performed on $0.1 \mu \mathrm{l}$ of the product of the primary PCR by testing $20 \mu \mathrm{l}$ of a 1 in 200 dilution in water. This optimal dilution was determined in a dilution experiment; under-dilution resulted in competition between the primers in the nested mix and excess from the primary PCR; overdilution resulted in lower sensitivity. Final buffer concentrations in the 50- $\mu$ l PCR sample were the same as in the primary PCR. except that dNTP and polymerase concentrations were halved $(0 \cdot 1 \mathrm{~mm}$ each dNTP and 0.35 units/sample, respectively) and different primers (internal S331+internal P456, or internal $\mathrm{S} 331+$ external $\mathrm{S} 114 ; 5 \mu \mathrm{g} / \mathrm{ml}$ each) were used. Primers P456 and S331 (Severn Biotech) are equivalent to oligonucleotides 2 and 3, respectively, of Burg et al.." but P456 was $5^{\prime}$ labelled with biotin, instead of the T7 RNA polymerase promoter sequence. Nested PCR was subjected to 17 temperature cycles.

\section{Results}

\section{Sensititit}

All modifications to the PCR procedure in order to improve its sensitivity were based on dilution experiments of $R_{H}$ strain tachyzoites in water. Positive results were regularly attainable with 64-100 parasites after primary PCR and with 1-4 parasites after nested PCR in samples which had been boiled for $20 \mathrm{~min}$ in the presence of $10^{5} \mathrm{rat}$, mouse or human leucocytes in water. In fig. 1, a 194-bp band is visible with ethidium bromide stain at all parasite dilutions in rat leucocytes down to 64 parasites after primary PCR, and a 160-bp band to two parasites after nested PCR. Faint bands of other molecular size were frequently visible after primary PCR, but not after nested PCR. In the absence of mammalian leucocyctes, similar sensitivity was achieved, but the PCR was inhibited by high parasite numbers $\left(>10^{4}\right)$. Positive results were also possible in the presence of higher leucocyte concentrations; a band was easily visible after nested PCR when six parasites (the lowest number tested) were assayed in the presence of $6 \times 10^{5}$ rat leucocytes, and faintly visible in the presence of $6 \times 10^{6}$ leucocytes.

Small volumes of highly concentrated leucocytes, especially with erythrocyte contamination, produced very viscous and particulate sample homogenates which were difficult to handle. However, clarification by low speed centrifugation markedly reduced test sensitivity (fig. 2). Sensitivity was reduced from between two and eight parasites without clarification to $10^{4}$ parasites after clarification before both PCR steps. The inclusion of Triton X-100 (essential in the reaction 
Table I. Time course of $R_{H}$ infection in Cotton rats and mice

\begin{tabular}{|c|c|c|c|c|c|c|}
\hline \multirow{2}{*}{$\begin{array}{l}\text { Time after } \\
\text { infection (h) }\end{array}$} & \multirow{2}{*}{$\begin{array}{l}\text { Number } \\
\text { of rats }\end{array}$} & \multicolumn{2}{|c|}{$\begin{array}{c}\text { Number of } \\
\text { positive results by }\end{array}$} & \multirow{2}{*}{$\begin{array}{l}\text { Number } \\
\text { of mice }\end{array}$} & \multicolumn{2}{|c|}{$\begin{array}{l}\text { Number of } \\
\text { positive results by }\end{array}$} \\
\hline & & culture* & PCR $\dagger$ & & culture* & PCR $\dagger$ \\
\hline 16 & 3 & 2 & $1(1)$ & 4 & 2 & $2(0)$ \\
\hline 24 & 3 & 1 & $1(0)$ & 4 & 2 & $4(2)$ \\
\hline 40 & 3 & 3 & $3(3)$ & 4 & 4 & $4(2)$ \\
\hline 48 & 3 & 3 & $3(2)$ & 4 & 3 & $4(4)$ \\
\hline 66 & 3 & 2 & $3(2)$ & 4 & 3 & $4(2)$ \\
\hline Total & 15 & 11 & $11(8)$ & 20 & 14 & $18(10)$ \\
\hline
\end{tabular}

\footnotetext{
* Parasites identified in peritoneal exudate of mice 6-10 days after inoculation of specimen. $\dagger$ Results of water-washed leucocytes compared with those without water wash (in parentheses).
}

Table II. Time course of infection with Beverley strain in Cotton rats and mice

\begin{tabular}{|c|c|c|c|c|c|c|}
\hline \multirow{2}{*}{$\begin{array}{c}\text { Time after } \\
\text { infection (days) }\end{array}$} & \multirow{2}{*}{$\begin{array}{l}\text { Number } \\
\text { of rats }\end{array}$} & \multicolumn{2}{|c|}{$\begin{array}{l}\text { Number of } \\
\text { positive results by }\end{array}$} & \multirow{2}{*}{$\begin{array}{l}\text { Number } \\
\text { of mice }\end{array}$} & \multicolumn{2}{|c|}{$\begin{array}{c}\text { Number of } \\
\text { positive results by }\end{array}$} \\
\hline & & culture* & PCR $†$ & & culture* & PCR \\
\hline 1 & 1 & 0 & $0(0)$ & 2 & 0 & $0(0)$ \\
\hline 2 & 1 & 0 & $0(0)$ & 2 & 0 & $2(2)$ \\
\hline 3 & 1 & 0 & $1(1)$ & 2 & 0 & 1 (1) \\
\hline 4 & 1 & 0 & $1(0)$ & 2 & 0 & $2(2)$ \\
\hline 7 & 1 & 1 & $1(1)$ & 2 & 1 & $2(1)$ \\
\hline 10 & 1 & 0 & $1(1)$ & 2 & 0 & $1(0)$ \\
\hline 14 & 1 & 1 & $1(1)$ & 2 & 0 & $1(1)$ \\
\hline 17 & 1 & 0 & $1(1)$ & 2 & 0 & $1(1)$ \\
\hline 21 & 1 & 0 & $1(0)$ & 2 & 1 & $1(0)$ \\
\hline 24 & 1 & 1 & $0(0)$ & 2 & 0 & $1(0)$ \\
\hline 28 & 2 & 0 & $2(1)$ & 2 & 0 & $2(0)$ \\
\hline 31 & 1 & 1 & $1(1)$ & 2 & 0 & $1(0)$ \\
\hline 35 & 1 & 0 & $0(0)$ & & & \\
\hline 38 & 1 & 0 & $1(1)$ & & & \\
\hline Total & 15 & 4 & $11(8)$ & 24 & 2 & $15(8)$ \\
\hline
\end{tabular}

$*, \dagger$ See footnotes to table I.

buffer, especially with Promega polymerase) during sample boiling did not release more DNA into the supernate.

When dilutions of $R_{H}$ tachyzoites in the presence of $10^{5}$ rat leucocytes were extracted with detergent at $55^{\circ} \mathrm{C}$, then organic solvents, the maximum sensitivity after nested PCR was 16 parasites. There were problems in achieving consistent recoveries from small samples with this method, and in some experiments the final sensitivity was considerably poorer than this figure. At the primary PCR stage the maximum sensitivity was $10^{3}$ parasites. Sensitivity was not improved by including proteinase $\mathrm{K}$ in the lysis buffer. In the absence of rat leucocytes, parasite DNA was not detectable at any dilution tested from $10^{4}$ downwards.

\section{Specificity}

A positive nested PCR result confirmed the specificity of the primary PCR product. Bands of $160 \mathrm{bp}$ with nested primers S1 14 and S331, or 97 bp with S331 and $\mathrm{P} 456$, were seen consistently with positive control samples known to contain toxoplasma $R_{H}$ tachyzoite DNA. Uninfected leucocyte negative controls pro- duced no bands. In addition, the primary PCR product was transferred by Southern blotting to a Genescreen plus nylon membrane (Dupont UK, Stevenage) and hybridised with primer S331, labelled with digoxygenin-dUPT by a 3' end-labelling kit (BCL Ltd, Lewes) according to the manufacturer's instructions. In positive control samples, a 194-bp band was detectable by anti-digoxygenin immunoassay performed according to kit instructions.

Adenovirus, cytomegalovirus, herpes simplex virus, $S$. aureus, $C$. albicans and $P$. carinii at all concentrations tested in the presence of $10^{5}$ rat leucocytes produced negative results. In each case, a positive control of $10^{2}$ toxoplasma tachyzoites added to the highest pathogen concentration yielded a visible band.

\section{$R_{H}$ strain DNA in rat and mouse blood}

PCR and isolation in mice were compared for detection of toxoplasma infection in leucocyte fractions from Cotton rat or mouse (BK: TO strain) blood samples, collected at five time intervals after intraperitoneal infection with $\mathrm{R}_{\mathrm{H}}$ strain (table I). The methods had similar sensitivity with both rat and 
mouse blood. The results reported for PCR are those which were obtained after washing the leucocytes with water to reduce haemoglobin content. Fewer positive results were obtained if this step was omitted (table I). Both total sample volumes collected and the yield of leucocytes varied considerably throughout the experiment. With rats, positive $\mathrm{PCR}$ results were obtained from samples with leucocyte content in the range $(0.4-3.0) \times 10^{5}$. With mice, the corresponding figures were $(0 \cdot 18-3 \cdot 0) \times 10^{5}$ leucocytes. In a repeat $\mathrm{R}_{\mathrm{H}}$ strain time course. employing two rats at each time point, the number of positive PCR results increased from 7 of 10 to 8 of 10 when the leucocyte concentration in the sample was adjusted to fall within this range $\left(1 \times 10^{5}\right.$ leucocytes in eight cases; $0.5 \times 10^{5}$ and $0.3 \times 10^{5}$, respectively, in two cases where the starting concentration was $\left.<1 \times 10^{5}\right)$. The original leucocyte content of the sample that became positive was $12.3 \times 10^{5} ;$ in the two that remained negative, it was $9 \cdot 2 \times 10^{5}$ and $6 \cdot 0 \times 10^{5}$, respectively; and the remainder were within the range $(0 \cdot 3-2 \cdot 5) \times 10^{5}$. In animal culture, 7 of 10 specimens gave positive results.

\section{Beverley strain DNA in rat and mouse blood}

Blood samples collected from mice and rats at 12 or 14 time intervals, respectively, after infection produced more positive results in PCR than in animal culture (table II). Again, sample volumes and leucocyte yields were variable. The ranges for positive $\mathrm{PCR}$ results were $(0 \cdot 7-23.0) \times 10^{5}$ leucocytes from rats and $(0 \cdot 3-4.0) \times 10^{5}$ from mice.

\section{Discussion}

Samples containing cells are normally digested with proteinase $\mathrm{K}$ and detergent, then extracted with organic solvents in preparation for PCR assays. ${ }^{5,8,12}$ However, DNA extraction with organic solvents involves a risk of losing any pathogen DNA which may be present in small samples. ${ }^{13}$ Our results with dilution series of $\mathrm{R}_{\mathrm{H}}$ parasites confirmed this problem. especially when dilutions were carried out in the absence of rat leucocytes. Our ability to detect repeatedly one to four parasites in the presence of rodent leucocytes after simply boiling in water suggests that there is no need to use more elaborate DNA extraction procedures. The concentration of leucocytes added in most dilution experiments was $10^{5} / 20 \mu \mathrm{l}$ but it was also possible to detect six parasites in $6 \times 10^{6}$ leucocytes, which is within the normal range for a $1-\mathrm{ml}$ sample of human blood. As the parasites are likely to be present as infected cells ${ }^{4}$ rather than free tachyzoites, with $\geqslant 16$ parasites/cell ${ }^{14}$ the test is capable of detecting one infected cell in a $1-\mathrm{ml}$ sample. Enhancing this sensitivity level may be difficult because attempting to test a leucocyte sample concentrated from $10 \mathrm{ml}$ of blood could result in PCR inhibition and it would increase the technical difficulty of handling small heterogeneous preparations. It was found to be important to test the whole sample; sensitivity was reduced if samples were clarified at any stage.

Toxoplasma DNA was also detected in leucocytes from experimentally infected animals. Combining all these experiments, the range of leucocyte concentrations within which positive PCR results were obtained was $(0 \cdot 18-23 \cdot 0) \times 10^{5} /$ sample. However, there was some evidence that the parasite DNA may be more easily detectable when the leucocyte content was $<10^{6} /$ sample. Therefore, we consider it advisable to test samples with $>10^{6}$ leucocytes at more than one dilution. Significant erythrocyte contamination magnified the specimen handling problems and this frequently amounted to $>10$ times the leucocyte content. Haemoglobin is claimed to inhibit PCR. ${ }^{12}$ A final wash with water was necessary to remove haemoglobin from leucocyte preparations. The problem was demonstrated by the failure to detect $R_{H}$ strain DNA in some specimens subsequently found to be positive by animal culture, unless this water wash stage was performed. High erythrocyte contamination $(>$ $10 \times$ leucocyte concentration) was present in $10(59 \%)$ of 17 specimens that produced negative results in the absence of a water wash, compared with only $3(19 \%)$ of 16 that produced positive results. Counts were not available from two positive specimens. Parasitaemia was demonstrated throughout $R_{I I}$ strain infection $(16-66 \mathrm{~h})$, which is not surprising in a virulent infection. Even though PCR was no more sensitive than animal culture, parasitaemia was detected earlier and at least as effectively as reported elsewhere. ${ }^{6,12}$ PCR was an improvement over animal isolation for the samples from rats or mice infected with the Beverley strain. This probably results from decreased sensitivity of the culture method rather than improved PCR sensitivity and reflects the relative virulence of the strains. Small numbers of the virulent $R_{H}$ strain are more likely to result in demonstrable infection in animals. However, as cyst-forming strains like the Beverley strain are the type usually isolated from human infections, the greater sensitivity of PCR is encouraging.

The detection of toxoplasma in blood at 2-38 days after infection with the Beverley strain indicates that parasitaemia is not transient in animals. It suggests that PCR may still provide valuable diagnostic information in human infections several weeks after onset.

The test as described is fairly simple to perform and could provide results within $10 \mathrm{~h}$ of specimen receipt. Its sensitivity and specificity are currently high and there is scope for enhanced sensitivity through biotinavidin enzymatic amplification methods ${ }^{15}$ via the biotin-labelled internal primer after nested PCR. The efficacy of the technique on human blood samples from patients with clinical toxoplasmosis was concurrently investigated. ${ }^{16}$ If PCR compares as favourably with animal culture as it does in this study, it 
should replace the latter technique as the method of choice for demonstrating the presence of $T$. gondii in clinical specimens, particularly blood.

\section{References}

1. Holliman RE. Toxoplasmosis and the acquired immune deficiency syndrome. $J$ Infect $1988 ; 16$ : 121-128.

2. Luft BJ, Remington JS. Toxoplasmosis of the central nervous system. In: Remington JS (ed) Current clinical topics in infectious disease. New York, McGraw-Hill. 1985; 6: 315-358.

3. Daffos F, Forestier F, Cappela-Pavlovsky M et al. Prenatal management of 746 pregnancies at risk for congenital toxoplasmosis. N Engl J Med 1988; 318: 271-275.

4. Remington JS, Desmonts G. Toxoplasmosis. In: Remington JS, Klein JO (eds) Infectious diseases of the fetus and newborn infant, 3rd edn. Philadelphia, WB Saunders. 1990: 89-195.

5. Hayden JD, Ho SA, Hawkey PM, Taylor GR, Quirke P. The promises and pitfalls of PCR. Rev Med Microbiol 1991; 2: 129-137.

6. Savva D, Morris JC, Johnson JD, Holliman RE. Polymerase chain reaction for detection of Toxoplasma gondii. $J \mathrm{Med}$ Microbiol 1990; 32: 25-31.

7. Holliman RE, Johnson JD, Savva D. Diagnosis of cerebral toxoplasmosis in association with AIDS using the polymerase chain reaction. Scand J Infect Dis 1990; 22: 243-244.

8. Burg JL, Grover CM, Pouletty P, Boothroyd JC. Direct and sensitive detection of a pathogenic protozoan, Toxoplasma gondii, by polymerase chain reaction. J Clin Microbiol $1989 ; 27: 1787-1792$
We are grateful for a grant from the Scottish Home and Health Department (Ref: K/MRS/50/C1429), to J. Gow, C. Woodall and B. B. Cohen for advice on PCR, and to Ms V. MacFarquhar for secretarial assistance.

9. Araujo FG, Remington JS. Antigenemia in recently acquired acute toxoplasmosis. $J$ Infect Dis $1980 ; 141: 144-150$

10. van Knapen F, Panggabean SO, van Leusden J. Demonstration of toxoplasma antigen containing complexes in active toxoplasmosis. J Clin Microbiol 1985; 22: 645-650.

11. Hassl A, Aspöck H, Flamm H. Circulating antigen of Toxoplasma gondii in patients with AIDS: significance of detection and structural properties. Zentralbl Bakteriol Mikrobiol Hyg 1988; A270: 302-309.

12. Weiss LM, Udem SA, Salgo M, Tanowitz HB, Wittner M Sensitive and specific detection of toxoplasma DNA in an experimental murine model: use of Toxoplasma gondiispecific cDNA and polymerase chain reaction. $J$ Infect Dis 1991; 163: 180-186.

13. Wages JM, Hamdallah M, Calabro MA et al. Clinical performance of a polymerase chain reaction testing algorithm for diagnosis of HIV-1 infection in peripheral blood mononuclear cells. J Med Virol 1991; 33: 58-63.

14. Beverley JKA. Some aspects of toxoplasmosis, a world wide zoonosis. In: Soulsby EJL (ed) Parasitic zoonoses: clinical and experimental studies. New York, Academic Press. 1974: 1-25.

15. Bronstein I, Voyta JC, Lazzari KG, Murphy O, Edwards B, Kricka LJ. Rapid and sensitive detection of DNA in southern blots with chemiluminescence. Biotechniques 1990; 8: 310-314.

16. Ho-Yen DO, Joss AWL, Balfour AH, Smyth ETM, Baird D, Chatterton JMW. An assessment of Toxoplasma gondii parasitaemia by PCR in human blood samples. J Clin Pathol 1992; in press. 